\title{
Parathyroid Hormone-Related Protein as a Mediator of Renal Damage: New Evidence from Experimental as well as Human Nephropathies
}

\author{
Ricardo J. Bosch et al.* \\ Laboratory of Renal Physiology and Experimental Nephrology, Department of Physiology \\ Spain
}

\section{Introduction}

End-stage renal disease (ESRD) is a public health problem worldwide, with an increasing incidence and prevalence, poor prognosis and high cost (Ministerio de Salud, 2005). In 2005 the prevalence of ESRD in the USA was 1,131 patients per million inhabitants, with an incidence of 296 new patients per year per million inhabitants. In 2008, the adjusted incident rate for patients age 45-64 fell to the same level seen in $1998-605$ per million population. The rate for those aged 75 and older declined 0.9 percent between 2007 and 2008 . However, racial and ethnic discrepancies persist with 2008 incident rates in the African American and Native American populations 3.6 and 1.8 times greater, respectively, than the rate among whites, and the rate in the Hispanic population 1.5 times higher than that of non-Hispanics (U. S. Renal Data System, 2010).

Diabetic nephropathy (DN) is one of the major causes of ESRD in the Western world. The incidence of nephropathy owing to type 1 diabetes is declining; however, diabetes mellitus type 2 is now the most common single cause of renal insufficiency in the USA, Japan and Europe (Tisher \& Hostetter, 1994). It has been estimated that $4 \%$ of the world's current population is diabetic, and that in Europe there will be more than 32 million patients with diabetes in 2010, causing an increase in related complications, such as DN. This pathology has been recognized as a worldwide medical catastrophe (Ziyadeh \& Sharma, 2003).

DN appears clinically in 10-50\% of diabetic patients after 10-20 years of evolution of the disease. These patients show a progressive increase in urinary excretion of protein, starting from an initial microalbuminuria to clear nephrotic syndrome with progressive decline of renal function (Cooper et al., 1999; Katoh et al., 2000; Tisher \& Hostetter, 1994; Yotsumoto et al., 1997).

\footnotetext{
* María Isabel Arenas ${ }^{1,2}$, Montserrat Romero ${ }^{1}$, Nuria Olea ${ }^{1}$, Adriana Izquierdo ${ }^{1}$, Arantxa Ortega ${ }^{1}$, Esperanza Vélez ${ }^{1}$, Jordi Bover ${ }^{3}$, Juan C. Ardura ${ }^{4}$ and Pedro Esbrit ${ }^{4}$ ${ }^{1}$ Laboratory of Renal Physiology and Experimental Nephrology, Department of Physiology, 'Department of Cell Biology and Genetics, University of Alcalá, Alcalá de Henares,

${ }^{3}$ Nephrology Department, Fundació Puigvert, Barcelona

"Bone and Mineral Metabolism Laboratory, Instituto de Investigación Sanitaria-Fundación Jiménez Díaz, Madrid, Spain
} 
$\mathrm{DN}$ is characterized by hypertrophy of the glomerular and tubular structures of the kidneys, thickening of the basement membrane, glomerular hyperfiltration and accumulation of extracellular matrix components in the glomerular mesangium (glomeruloesclerosis) and tubular interstitium (tubulointerstitial fibrosis).

The thickening of the basement membrane as well as the expansion of mesangial matrix is associated with the deterioration of glomerular function (proteinuria) (Osterby et al., 2001, 2002; White \& Bilous, 2000). Besides glomerulosclerosis, typically associated to DN, tubulointerstitial changes, including fibrosis, appear to be critical during the final progression of DN. In fact, tubulointerstitial fibrosis is the factor that best correlates with the progressive loss of renal function (White \& Bilous, 2000). Although several aspects of DN are well known, its pathogenesis at molecular level is poorly understood.

Something similar occurs with acute renal injury (ARI). This pathology has a significant prevalence $(5 \%)$ in hospitalized patients. The maintenance therapy in these patients, in which dialysis treatment is required, has important socio-economic implications (Nolan \& Anderson, 1998). Thus, the survival range in the ARI has not improved in recent years. ARI is a potentially reversible multi-causal entity that is characterized by a tubuloepithelial renal necrosis, followed by an augmented proliferation and tubuloepithelial regeneration (Brady et al., 1996).

Depending on the intensity of and exposure time to the agent inducing the initial damage, ARI can progress to chronic renal disease - the evolution of which is an irreversible process characterized by the loss of nephrons and the development of fibrosis - and thus to ESRD (Chevalier, 2006; Remuzzi \& Bertani, 1998).

The study of the mechanisms implicated in renal fibrosis, the final pathway to different nephropathies which can progress to ESRD, is very interesting as it involves the search for, and evaluation of, agents with therapeutic applications.

In the last decade several investigations have demonstrated the implication of the parathyroid hormone related protein (PTHrP) in renal injury. This protein was discovered at the end of the 1980s as the factor responsible for humoral hypercalcemia of malignancy, and today is the object of study as a possible new therapeutic target in some pathophysiological conditions (Clemens et al., 2001).

At present, it is well known that PTHrP is a widespread factor in normal tissues, including kidney, where it has autocrine/paracrine/intracrine actions through PTH/PTHrP type 1 receptor (PTH1R) (Clemens et al., 2001). Renal PTHrP overexpression is a common event in several acute as well as chronic nephropathies (Fiaschi-Taesch et al., 2004; Izquierdo et al., 2006; Largo et al., 1999; Lorenzo et al., 2002; Rámila et al., 2008; Santos et al., 2001). During the last years, studies to define the physiopathological role of PTHrP in the renal context have been carried out, using experimental models of tubulointerstitial or glomerular damage. In both entities the direct implication of PTHrP has been demonstrated, showing the important role of this protein in the mechanisms that regulate the cell cycle, inflammation and fibrosis, which indicates the possibility of new pathways of therapeutic intervention (Ortega et al., 2006; Rámila et al., 2008; Romero et al., 2010).

The following paragraphs describe the emerging role of the PTHrP system in acute and chronic renal injury, product of intense investigation for over a decade.

\section{PTHrP in acute renal injury}

Pioneer studies by Soifer et al. (1993) at the beginning of the 90's suggested the implication of PTHrP in the mechanisms of injury and/or repair of the tubular epithelium after ischemic ARI. From then on, the majority of investigations have studied experimental nephropathies 
characterized by tubular affectation (Fiaschi-Taesch et al., 2004; Largo et al., 1999; Lorenzo et al., 2002; Ortega et al., 2005; Santos et al., 2001).

Ischemic and toxic injury to renal tubular epithelial cells can cause both acute and chronic renal failure depending on the intensity of and exposure time to the damage (Humes et al., 1995; Lieberthal \& Levine, 1996). Proliferation of injured tubule cells appears to be important for timely tubular recovery after renal injury, and for subsequent functional recovery of the damaged kidney. Several growth factors and cytokines, acting in an autocrine and paracrine manner, appear to participate in the repair process of the tubular epithelium in this setting (Fiaschi-Taesch et al., 2004; Gobe et al., 2000; Humes et al., 1995; Matsumoto \& Nakamura, 2001; Vukicevic et al., 1998).

The mitogenic features of PTHrP and its early overexpression after renal injury in experimental models of acute renal failure (ARF), induced by either ischemia or nephrotoxins, initially suggested that PTHrP could participate in the regenerative process after ARI (Santos et al., 2001; Soifer et al., 1993). However, this putative role of PTHrP in the acutely damaged kidney was intriguing, since the PTH1R gene was found to be rapidly downregulated following ARI (Santos et al., 2001; Soifer et al., 1993). This is in sharp contrast to other well characterized renal mitogens, such as epidermal growth factor (EGF) and hepatocyte growth factor (HGF), whose receptors are upregulated after ARI (Humes et al., 1995; Matsumoto \& Nakamura, 2001). Moreover, the PTH1R was also found to decrease in the kidney of protein-overloaded rats with tubulointerstitial damage (Largo et al., 1999). Current evidence suggests that factors other than PTHrP or Ang II are likely to account for the PTH1R downregulation associated with kidney damage (Fiaschi-Taesch et al., 2004; Lorenzo et al., 2002). It is interesting to mention in this context that spliced variants of this receptor showing low expression in the cell surface have shown to be present in the kidney (Jobert et al., 1996). In addition, the PTH1R can be internalized into the nucleus of renal tubular cells (Watson et al., 2000). The pathophysiological relevance of these mechanisms for the PTHrP action in the damaged kidney is presently unknown. The hypothetical beneficial effects of PTHrP as a mitogen in ARI was further questioned when considering that targeted delivery of PTHrP to the proximal tubule in mice failed to provide protection against renal ischemia or folic acid injury (Fiaschi-Taesch et al., 2004). Moreover, experimental data using the latter model in rats showed that pretreatment with Ang II blockers abolished the PTHrP upregulation but not tubular hyperplasia (Ortega et al., 2005). Thus, current evidence makes it unlikely that PTHrP plays a significant role in the regenerative process after ARI.

Renal PTHrP upregulation was also observed in other experimental nephropathies. Thus, chronic cyclosporin administration, which induces tubular atrophy and interstitial fibrosis, was shown to be associated with an increased PTHrP expression, at both mRNA and protein levels, in the rat renal cortex (Garcia-Ocaña et al., 1998). Moreover, PTHrP mRNA was found to increase sequentially in the renal cortex during the development of proteinuria in a rat model of tubulointerstitial damage after protein overload (Largo et al., 1999). Interestingly, in the latter model, dramatic PTHrP immunostaining was revealed in glomerular mesangial cells, associated with an increased mesangial growth and matrix expansion in those rats with intense proteinuria (Largo et al., 1999). These findings suggest that PTHrP could play a role in the mechanisms associated with progression of kidney damage.

\section{Interaction between PTHrP and angiotensin II in the damaged kidney}

The renin-angiotensin system is known to play an important pathogenic role in the mechanisms of renal injury (Egido, 1999; Harris \& Martinez-Maldonado, 1995). In fact, the 
main agonist of this system, Ang II, can be envisioned as a growth factor which can promote the progression of kidney damage (Mezzano et al., 2001; Ruiz-Ortega \& Egido, 1997). Activation of components of the renin-angiotensin system, including Ang II, locally in the kidney, has been shown to occur early in various experimental models of ARI, e.g., folic acid-induced nephrotoxicity or ischemia/reperfusion (Allred et al., 2000; Kontogiannis \& Burns, 1998; Ortega et al., 2005; Santos et al., 2001). Moreover, Ang II antagonists exert beneficial effects on renal function in these models (Abdulkader et al., 1998; Long et al., 1993; Ortega et al., 2005).

Recent data strongly suggest that PTHrP might be involved in the mechanisms related to Ang II-induced renal injury. Exogenously administered Ang II, via its type 1 (AT1) receptor, increases PTHrP expression in glomerular and tubular cells as well as in vascular smooth muscle cells both in vivo and in vitro (Lorenzo et al., 2002; Noda et al., 1994; Pirola et al., 1993). Interestingly, a significant correlation between PTHrP overexpression and tubular damage and fibrosis was observed in the rat kidney after systemic Ang II infusion (Lorenzo et al., 2002). Furthermore, in nephrotoxic ARI, the improvement of renal function by Ang II antagonists was associated with inhibition of PTHrP overexpression (Ortega et al., 2005). Collectively, current data suggest that: 1) Ang II is a likely candidate responsible for PTHrP overexpression; and 2) PTHrP might contribute to the deleterious effects of Ang II, in the damaged kidney. These findings have established a new rationale for further studies focused on the putative contribution of PTHrP to the mechanisms of renal damage.

\section{PTHrP in renal inflammation}

Inflammation involves complex molecular and cellular mechanisms which are activated against physical, chemical or biological aggressions. This process normally serves a positive biological goal (e.g., to overcome invasion of potentially deleterious agents), but it may have detrimental effects in chronic pathological settings, such as progressive renal disease (Chevalier, 2006; Rees, 2006; Remuzzi \& Bertani, 1998). Tubulointerstitial inflammation is a key event in a variety of nephropathies. Early after renal injury, damaged tubuloepithelial cells begin to overexpress proinflammatory cytokines and chemokines, which promote migration of monocytes/macrophages and T-lymphocytes to the renal interstitium (Muller et al., 1992; Rees, 2006). Both infiltrating leukocytes and damaged tubuloepithelial cells activate and induce proliferation of resident fibroblasts in the tubulointerstitial compartment. A severe and prolonged injury will determine a sustained activation of proinflammatory pathways, associated with overexpression of profibrogenic cytokines by tubulointerstitial cells leading to fibrogenesis and renal function loss (Strutz \& Neilson, 2003).

Early studies suggested that PTHrP might act as an important mediator of proinflammatory cytokines, namely tumour necrosis factor and interleukin-6, in multi-organ inflammation and rheumatoid arthritis (Funk, 2001). More recent studies have shown that PTHrP activates nuclear factor NF-kB and the expression of NF-kB-dependent cytokines and chemokines [e.g., IL-6 and monocyte chemoattractant protein-1 (MCP-1)] in different cell types (Guillén et al., 2002; Martín-Ventura et al., 2003). PTHrP and MCP-1 were found to colocalize in smooth muscle cells in human atherosclerotic plaques (Ishikawa et al., 2000; Martín-Ventura et al., 2003; Nakayama et al., 1994).

Moreover, our results in mice with unilateral ureteral obstruction -a well characterized model of renal inflammation- have shown the critical role of PTHrP in this condition 
(Rámila et al., 2008). In this study, PTHrP was found to be upregulated, even in PTHrPoverexpressing mice. In contrast to previous observations in ischemic or nephrotoxic renal injury (Rámila et al., 2008), PTH1R was not downregulated after ureteral obstruction in mice. Interestingly, an upregulation of both PTHrP and PTH1R was recently observed in the kidney of diabetic mice (Izquierdo et al., 2006). Furthermore, our recent in vitro findings indicate that PTHrP upregulates several proinflammatory factors in tubuloepithelial cells and promotes monocyte/macrophage migration. Moreover, ERK mediated NF-kB activation appears to be an important mechanism whereby PTHrP triggers renal inflammation. These data suggest that PTHrP might be envisioned as a new inflammation marker and a potential therapeutic target in the obstructed kidney (Rámila et al., 2008). Finally, since sustained renal inflammation is closely related to fibrogenesis, these data point to PTHrP as a likely pro-inflammatory and pro-fibrogenic cytokine in the damaged kidney.

\section{PTHrP in renal cell apoptosis}

Apoptosis is considered to be an important component of the acute response of the tubular epithelium to injury (Basnakian et al., 2002; Kaushal et al., 2004). Previous studies showed that PTHrP can inhibit apoptosis in several cell types like pancreatic $\beta$-cells and chondrocytes (Cebrián et al., 2002; Henderson et al., 1995). At least in the latter cells, this antiapoptotic effect appears to involve PTHrP interaction with the PTH1R, and also its internalization into the nucleus (Henderson et al., 1995). We recently found that PTHrP, interacting with the PTH1R, directly acts as a survival factor for renal tubulointerstitial cells by a dual mechanism involving $\mathrm{Bcl}-\mathrm{X}_{\mathrm{L}}$ upregulation and activation of the phosphatidylinositol-3 kinase/Akt/Bad pathway (Ortega et al., 2006). Our data, using PTHrP-overexpressing mice with folic acid-induced ARF, suggest that this PTHrP action might have detrimental consequences in the injured kidney. These mice showed a significant delay in renal function recovery and higher focal areas of tubulointerstitial fibrosis than normal mice, associated with a decrease in apoptotic tubulointerstitial cells (Ortega et al., 2006). The rationale for this association might come from the fact that apoptosis of interstitial fibroblasts appears to be a mechanism to prevent fibrogenesis (Lieberthal \& Levine, 1996; Ortiz et al., 2000).

\section{PTHrP in chronic renal injury: Diabetic Nephropathy (DN)}

$\mathrm{DN}$ is characterized by the development of proteinuria and subsequent glomerulosclerosis, conditions which are always preceded by the development of an early hypertrophic process in the glomerular compartment (Wolf \& Ziyadeh, 1999). Hypertrophy of podocytes, associated with a decrease in their number per glomerulus is known to occur in diabetes (Kriz et al., 1998; Mifsud et al., 2001; Pagtalunan et al., 1997). Over time, podocyte hypertrophy might become a maladaptive response leading to glomerulosclerosis.

Although the mechanisms by which high glucose (HG) leads to renal cell hypertrophy are still incompletely understood, it appears to involve cell entry into the cell cycle -associated to cyclin $D_{1}$ kinase activation early in $G_{1}$ - and subsequent arrest at the $G_{1} / S$ interphase implicating inhibition or insufficient activation of cyclin $\mathrm{E}$ kinase, to permit progression into $S$ phase, and therefore, arrest of cell cycle progression followed by an increase in cell protein synthesis (Huang \& Preisig, 2000).

Recent studies have shown that HG-induced hypertrophy involves an early activation of the renin-angiotensin system, followed by an induction of TGF- $\beta_{1}$, which in turn activates a cell 
cycle regulatory protein, the cyclin dependent kinase inhibitor (CDKI) p27Kip1 (Pantsulaia, 2006; Wolf et al., 1998; Xu et al., 2005).The interaction of p27Kip1 with the cyclin E kinase has been implicated in the inhibition of this late complex and thus the $\mathrm{G}_{1}$ progression (Ekholm \& Reed, 2000).

Previously we evaluated the expression of PTHrP in the kidney of mice with streptozotocin (STZ)-induced diabetes (Izquierdo et al., 2006). This animal model is characterized by development of renal hypertrophy and increased proteinuria early in the course of the disease (Gross et al., 2004). We found that diabetic mice showed a significant increase of both PTHrP and the PTH1R proteins expression associated with the development of both renal hypertrophy and proteinuria (Izquierdo et al., 2006). Interestingly, the regression analyses of these data also indicate that changes in the renal PTHrP/PTH1R system have predictive value on the early development of proteinuria in mice. Although the STZ model has limitations for assessing long-term histomorphological changes in the diabetic kidney (Gross et al., 2004); our findings might have pathophysiological implications since the amount of proteinuria is a reliable predictor of diabetic nephropathy (D'Amico \& Bazzi, 2003; Hirschberg, 1996).

In a more recent study, Romero et al (2010) observed that PTHrP plays a key role in the mechanisms of HG-induced podocyte hypertrophy. In these studies, HG-induced podocyte hypertrophy was inhibited by the presence of a specific PTHrP neutralizing antibody. Interestingly, in this condition $\mathrm{HG}$ also failed to upregulate the expression of the hypertrophy factor TGF- $\beta_{1}$.

Although PTHrP does not seem to affect podocyte apoptosis, it was shown to be able to modulate the expression of several positive as well as negative cell cycle regulatory proteins. In this way, while PTHrP (1-36) was shown to stimulate cyclin $\mathrm{D}_{1}$, thus promoting podocytes to enter into $G_{1}$, it also downregulates cyclin $E$, hence blocking the cell cycle later in $\mathrm{G}_{1}$. Moreover, PTHrP is able to upregulate the negative cell cycle regulatory protein p27Kip1 which plays a key role in diabetic cell hypertrophy by preventing activation of cyclin E activity and arresting the cell cycle later in $\mathrm{G}_{1}$ (Huang \& Preisig, 2000; Romero et al., 2010). Interestingly, Romero et al (2010) found that the pharmacological blockade of the PTH1R inhibited the p27Kip1 upregulation induced by both HG and AngII. Taken together, these data suggest that PTHrP might mediate the hypertrophic signalling acting in an autocrine/intracrine fashion through the PTH1R receptor.

To discern the mechanism involved in the stimulation of p27kip1 induced by both PTHrP and TGF- $\beta_{1}$, Romero et al (2010) performed two experimental approaches. First, they found that using a PTHrP siRNA inhibited the ability of HG and AngII to stimulate the upregulation of p27Kip1, albeit it could not prevent the TGF- $\beta_{1}$ upregulation of this protein. Secondly, on TGF- $\beta_{1}$ siRNA transfected podocytes, PTHrP (1-36) failed to induce both p27Kip1 overexpression and hypertrophy. Thus, suggesting that TGF- $\beta_{1}$ mediates both p27Kip1 upregulation and the hypertrophy response induced by PTHrP on HG conditions.

Interestingly, Romero et al (2010) observed that the glomerular expression of both TGF- $\beta_{1}$ and p27Kip1 are constitutively upregulated in PTHrP-overexpressing mice albeit, the latter was not accompanied by renal hypertrophy (Fiaschi-Taesch et al., 2004). This result seems plausible since the hypertrophic mechanism requires the entry into the cell cycle and subsequent arrest at the $G_{1} / S$ interphase. Several studies have demonstrated that in glomerular cells grown in HG ambient, initially, self-limited proliferation occurs due to generation of HG-induced growth factors, followed by cell cycle arrest in the $\mathrm{G}_{1}$ due to the expression of factors that block the checkpoint G1/S interphase and undergo cellular 
hypertrophy (Cosio, 1995; Huang \& Preisig, 2000; Isono et al., 2000; Wolf et al., 1992). Of considerable interest is the fact that previous studies on PTHrP-overexpressing mice have revealed the constitutive upregulation of various proinflammatory mediators (Rámila et al., 2008), including the vascular endothelial growth factor-1 (Ardura et al., 2008) without evidence of kidney damage in the absence of renal insult. In any case, these data strongly suggest that PTHrP might participate in the upregulation of glomerular TGF- $\beta_{1}$ and p27Kip1. Collectively, these results indicate that the renal PTHrP/PTH1R system is upregulated in streptozotozin-induced diabetes in mice, and appears to be involved with renal hypertrophy and adversely affects the outcome of DN. PTHrP also participates in the hypertrophic signalling triggered by HG on podocytes. In this condition, AngII induces the upregulation of PTHrP, which might induce the expression of TGF- $\beta_{1}$ and $\mathrm{p} 2 \mathrm{~K}_{\mathrm{Kip}}$. These findings provide new insights into the protective effects of AngII antagonists in DN, paving the way for new forms of intervention.

\section{PTHrP in renal fibrosis}

Renal fibrosis is recognized as the final common stage of main renal diseases, capable of progressing to chronic renal failure. Interstitial fibroblasts are the main cell type responsible for fibrogenesis, a process whereby these cells proliferate and become activated myofibroblasts (Ardura et al., 2008). Fibrosis of the kidney is known to be induced by both tubuloepithelial and infiltrating cells, as well as secretion of matrix compounds by both activated fibroblasts and tubular cells (Fan et al., 1999). In fact, an increased matrix synthesis and deposition, and loss of tubular structural integrity, are paramount events at later stages of fibrogenesis (Fan et al., 1999). Our previous studies indicate that the higher number of infiltrating macrophages was associated with increased fibroblast proliferation in the renal interstitium of folic acid-injured kidneys from PTHrP-overexpressing mice (Ortega et al., 2006). In these mice, an increased immunostaining for $\alpha$-smooth muscle actin ( $\alpha$-SMA), a marker of activated fibroblasts or myofibroblasts (Strutz et al., 2002), was also observed in the renal interstitium after folic acid nephrotoxicity (Ortega et al., 2006). Consistent with the latter in vivo finding, PTHrP (1-36) was found to stimulate $\alpha$-SMA expression in renal fibroblasts in vitro (Ortega et al., 2006). In addition, a higher immunostaining for both types I and IV collagens was observed in the renal interstitium of the obstructed kidneys from PTHrP-overexpressing mice than in their normal littermates (Ardura et al., 2008). In agreement with this finding, PTHrP (1-36) was found to stimulate the expression of both types of collagens, type- 1 procollagen and fibronectin in tubuloepithelial cells and renal fibroblasts in vitro. At least part of these effects was abolished by a PTH1R antagonist (Ortega et al., 2006).

Tubuloepithelial cells might also contribute to development of renal fibrosis by directly generating myofibroblasts through a process known as epithelial-mesenchymal transition (EMT) (Ardura et al., 2008; Liu, 2004). EMT is a multiple step process that requires the integration of several extrinsic and intrinsic pathways including loss of epithelia polarity, rearrangement of the F-actin cytoskeleton, associated with upregulation of many genes used as EMT markers (Kalluri \& Neilson, 2003). The latter includes, in addition to $\alpha$-SMA, which increases cell contractility and motility, extracellular matrix proteins such as fibronectin and several types of collagens, metalloproteases (MMPs) and integrin linked kinase (ILK). In addition, a decrease in the expression of proteins that keep basolateral polarity, namely, cytokeratin, and intracellular junctions, including the adherent junction protein E-cadherin 
and $\beta$-catenin, takes place in the renal tubuloepithelium during EMT (Bonventre, 2003; Cheng \& Lovett, 2003; Hinz et al., 2001; Kalluri \& Neilson, 2003; Strutz et al., 2002; Strutz \& Müller, 2006).

Activation of different signalling pathways acts as EMT intrinsic regulators: mitogen activated kinases (MAPKs), N-terminal c-Jun kinase (JNK), the RAS protein family, Wnt and Smad proteins and the transcription factors snail and slug (Kalluri \& Neilson, 2003; Liu, 2004; Martínez-Estrada et al., 2006). Several studies support the important role of various profibrogenic factors en the EMT process in the kidney. TGF- $\beta$ is the best known factor studied in this regard, and seems to involve activation of MAPKs and Smad proteins. In addition, activation of EGF receptor (EGFR) tyrosine kinase can trigger EMT in renal tubuloepitelial cells (Gore-Hyer et al., 2002; Grände et al., 2002; Liu, 2004; Zhuang et al., 2004; Zhuang et al., 2005).

PTHrP has been reported to promote EMT through interaction with vascular endothelial growth factor (VEGF) (Ardura et al., 2008). Interestingly in this scenario, it has been suggested that TGF- $\beta$ might act as a modulator of at least some PTHrP action through the PTH1R in renal cells. As previously mentioned, TGF- $\beta$ is able to mediate PTHrP-induced hypertrophy in renal glomerular visceral epithelial cells -podocytes- where PTHrP can induce TGF- $\beta$ upregulation (Romero et al., 2010). Furthermore, stimulation of the PTH1R may lead to EGFR transactivation, thus suggesting that PTHrP might play an important role in renal EMT (Ardura et al., 2010).

Recently, Ardura et al. (2010) expanded these studies and show that PTHrP is capable of inducing a variety of phenotypic changes related to EMT in tubuloephithelial cells. Hence, this peptide induced snail overexpression and its nuclear translocation, associated with the loss of ZO-1 and E-cadherin, key proteins in the maintenance of basolateral polarity and intercellular junction in renal tubuloepithelial cells. PTHrP also induced the phenotypic conversion to a fibroblast-like morphology, related to $\alpha$-SMA and ILK upregulation.

Moreover, these authors observed that PTHrP can increase TGF-expression at both gene and protein expression in cultured tubuloepithelial cells. Moreover, TGF- $\beta$ blockade by different manoeuvres was found to diminish renal fibrosis in both experimental models of renal damage and cultured renal cells, thus suggesting that TGF- $\beta$ acts as a downstream mediator of PTHrP. Interestingly, the same interaction between these two factors was observed in PTHrP-induced podocyte hypertrophy. This study suggests that PTHrP, TGF- $\beta$, EGF and VEGF might cooperate through activation of ERK1/2 to induce EMT in renal tubuloepithelial cells.

Interestingly, some EMT-related changes occur associated with PTHrP overexpression in the mouse obstructed kidney as recently reported by the laboratory of Dr Esbrit. This group also found that two important EMT mediators such as TGF- $\beta$ and p-EGFR proteins were elevated in this animal model associated with a targeted overexpression of PTHrP to the renal proximal tubule, thus suggesting that PTHrP might interact with TGF- $\beta$ or EGFR to modulate EMT (Ardura et al., 2010).

Collectively, all the available data demonstrate a major role for PTHrP in renal fibrogenesis due to its capacity to induce the expression of extracellular matrix proteins as well as by modulating EMT in renal tubuloepithelial cells.

\section{Conclusion}

The upregulation of the renal PTHrP/PTH1R system represents a common event in several experimental nephropathies. Current data support the notion that AngII is a major factor 
responsible for PTHrP overexpression in both ARI and diabetic nephropathy. In the former condition, PTHrP appears to contribute to the progression of renal damage by increasing tubulointerstitial cell survival, promoting inflammation and fibrogenesis, including epithelia to mesenchyme transition. In diabetic nephropathy, PTHrP can favor renal hypertrophy and proteinuria (Fig. 1). Collectively, available data strongly support the implication of PTHrP as a pathogenic factor in kidney disease, and provide novel insights into the protective effects of Ang II antagonists in various nephropathies, paving the way for new therapeutic approaches.

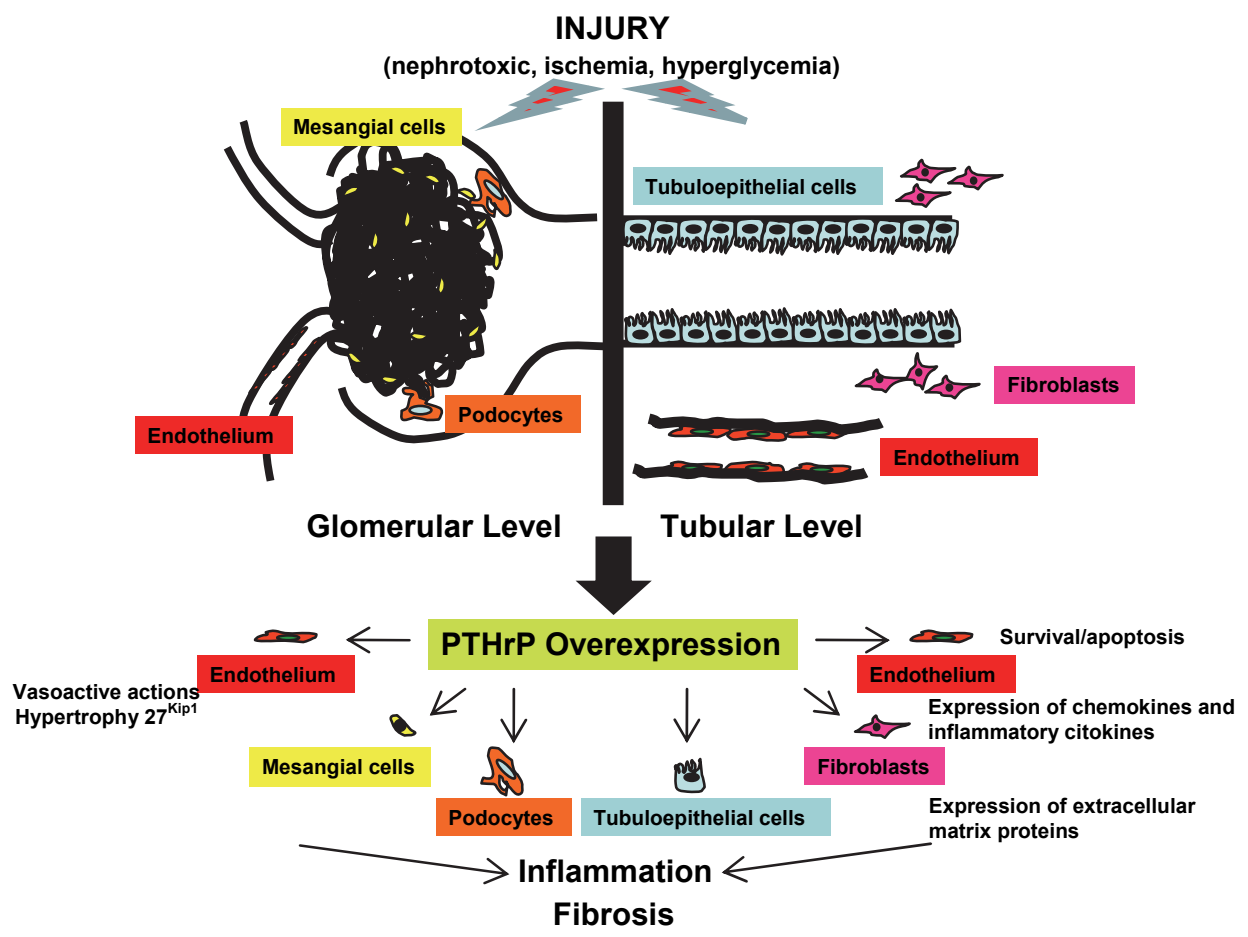

Fig. 1. Pathophysiology of PTHrP in acute and chronic renal injury.

\section{Acknowledgment}

A. Ortega was recipient of a research contract from Comunidad Autónoma de Madrid (SBIO-2083-2006). A. Izquierdo is currently Assistant Professor at the Rey Juan Carlos University (Alcorcón, Madrid). E. Vélez is currently Professor at the Jiménez Diaz Foundation School of Nursing; J. A. Ardura was supported by Conchita Rábago Foundation and RETICEF, and is currently a post-doctoral researcher at the Department of Pharmacology and Chemical Biology (University of Pittsburgh, Pittsburgh, PA). This work was supported in part by grants from Ministerio de Educación y Cultura of Spain (SAF200204356-C03-01, -02, -03 and SAF2006-08747) and Ministerio de Ciencia e Innovación 
(SAF2009-12009-C02-01), The Spanish Society of Nephrology, The Eugenio Rodríguez Pascual Foundation, and Instituto de Salud Carlos III (RETICEF RD06/0013/1002).

\section{References}

Abdulkader, R.C., Yuki, M.M., Paiva, A.C., \& Marcondes, M. (1988). Prolonged inhibition of angiotensin II attenuates glycerol-induced acute renal failure. Brazilian Journal of Medical and Biological Research, Vol. 21, No. 2, (February 1981), pp. 233-239, ISSN 0100-879X.

Allred, A.J., Chappell, M.C., Ferrario, C.M., \& Diz,D.I. (2000). Differential actions of renal ischemic injury on the intrarenal angiotensin system. American Journal of Physiology. Renal Physiology, Vol. 279, No. 4, (October 2000), pp. F636-F645, ISSN: 0363-6127.

Ardura J.A., Rayego-Mateos, S., Rámila D., Ortega-Ruiz, M., \& Esbrit P. (2010). Parathyroid hormone-related protein promotes epithelial-mesenchymal transition. Journal of the American Society of Nephrology, Vol. 21, No. 2, (February 2010), pp. 237-248, ISSN 1046-6673.

Ardura, J.A., Berruguete, R., Rámila, D., Álvarez-Arroyo, V., \& Esbrit, P. (2008). Parathyroid hormone-related protein interacts with vascular endothelial growth factor to promote fibrogenesis in the obstructed mouse kidney. American Journal of Physiology. Renal Physiology, Vol. 295, No. 2, (June 2008), pp. F415-F425, ISSN 03636127.

Basnakian, A.G., Kaushal, G.P., \& Shah, S.V. (2002). Apoptotic pathways of oxidative damage to renal tubular epithelial cells. Antioxidant $\mathcal{E}$ Redox Signaling, Vol. 4, No. 6, (December 2002), pp. 915-924, ISSN 1523-0864.

Bonventre, J.V. (2003). Dedifferentiation and proliferation of surviving epithelial cells in acute renal failure. Journal of the American Society of Nephrology, Vol. 14, No. Suppl 1, (June 2003), pp. S55-S61, ISSN 1046-6673.

Brady, H.R., Brenner, B.M., \& Lieberthal, W. (1996). Acute Renal Failure, In: The Kidney, $5^{\text {th }}$ B.M. Brenner, F.C. Rector (Eds.), pp. 1200-1252, W.B. Saunders ISBN-10: 9781416031055 ISBN-13: 978-1416031055, Philadelphia.

Cebrián, A., García-Ocaña, A., Takane, K.K., Sipula, D., Stewart, A.F., \& Vasavada, R.C. (2002). Overexpression of parathyroid hormone-related protein inhibits pancreatic beta-cell death in vivo and in vitro. Diabetes, Vol. 51, No. 10, (October 2002), pp. 3003-3013, ISSN 0012-1797.

Cheng, S., \& Lovett, D.H. (2003). Gelatinase A (MMP-2) is necessary and sufficient for renal tubular cell epithelial-mesenchymal transformation. The American Journal of Pathology, Vol. 162, No. 6, (June 2003), pp. 1937-1949, ISSN 1479-398.

Chevalier, R.L. (2006). Obstructive nephropathy: towards biomarker discovery and gene therapy. Nature Clinical Practice. Nephrology, Vol. 3, No. 2, (March 2006), pp. 157-168, ISSN 1745-8323, 1745-8331.

Clemens, T.L., Cormier, S., Eichinger, A., Endlich, K., Fiaschi-Taesch, N., Fischer, E., Friedman, P.A., Karaplis, A.C., Massfelder, T., Rossert, J., Schlüter, K.D., Silve, C., Stewart, A.F., Takane, K., \& Helwig, J.J. (2001). Parathyroid hormone-related protein and its receptors: nuclear functions and roles in the renal and cardiovascular systems, the placental trophoblasts and the pancreatic islets. British Journal of Phamacology, Vol. 134, No. 6, (November 2001), pp. 1113-1136, ISSN 14765381. 
Cooper, M.E., Vranes, D., Youssef, S., Stacker, S.A., Cox, A.J., Rizkalla, B., Casley, D.J., Bach, L.A., Kelly, D.J., \& Gilbert, R.E. (1999). Increased renal expression of vascular endothelial growth factor (VEGF) and its receptor VEGFR-2 in experimental diabetes. Diabetes, Vol. 48, No. 11 (November 1999), pp. 2229-2239, ISSN: 0012-1797.

Cosio, F.G. (1995). Effects of high glucose concentrations on human mesangial cell proliferation. Journal of the American Society of Nephrology, Vol. 5, No. 8, (February 1995), pp. 1600-1609, ISSN 1046-6673.

D'Amico, G., \& Bazzi, C. (2003). Pathophysiology of proteinuria. Kidney International, Vol. 63, No. 3, (March 2003), pp. 809-25, ISSN 0085-2538.

Egido, J. (1996). Vasoactive hormones and renal sclerosis. Kidney International, Vol. 49, No. 2, (February 1996), pp. 578-597, ISSN 0085-2538.

Ekholm, S.V., \& Reed, S.I. (2000). Regulation of G(1) cyclin-dependent kinases in the mammalian cell cycle. Current Opinion in Cell Biology, Vol. 12, No. 6, (December 2000), pp. 676-684, ISSN 0955-0674.

Fan, J.M., Ng, Y.Y., Hill, P.A., Nikolic-Paterson, D.J., Mu, W., Atkins, R.C., \& Lan, H.Y. (1999). Transforming growth factor-beta regulates tubular epithelial-myofibroblast transdifferentiation in vitro. Kidney International, Vol. 56, No. 4, (October 1999), pp. 1455-1467, ISSN 0085-2538.

Fiaschi-Taesch, N.M., Santos, S., Reddy, V., Van Why, S.K., Philbrick, W.F., Ortega, A., Esbrit, P., Orloff, J.J., \& Garcia-Ocaña, A. (2004). Prevention of acute ischemic renal failure by targeted delivery of growth factors to the proximal tubule in transgenic mice: the efficacy of parathyroid hormone-related protein and hepatocyte growth factor. Journal of the American Society of Nephrology, Vol. 15, No. 1, (January 2004), pp. 112-125, ISSN 1046-6673.

Funk, J.L. (2001). A role for parathyroid hormone-related protein in the pathogenesis of inflammatory/autoimmune diseases. International Immunopharmacology, Vol. 1, No. 6, (June 2001), pp. 1101-1121, ISSN 1567- 5769.

García-Ocaña, A., Gómez-Casero, E., Peñaranda, C., Sarasa, J.L., \& Esbrit, P. (1998). Cyclosporine increases renal parathyroid hormone-related protein expression in vivo in the rat. Transplantation, Vol. 65, No. 6, (March 1998), pp. 860-863, ISSN 00411337.

Gobe, G., Zhang, X.J., Willgoss, D.A., Schoch, E., Hogg, N.A., \& Endre, Z.H. (2000). Relationship between expression of Bcl-2 genes and growth factors in ischemic acute renal failure in the rat. Journal of the American Society of Nephrology, Vol. 11, No. 3, (March 2000), pp. 454-467, ISSN 1046-6673.

Gore-Hyer, E., Shegogue, D., Markiewicz, M., Lo, S., Hazen-Martin, D., Greene, E.L., Grotendorst, G., \& Trojanowska, M. (2002). TGF-beta and CTGF have overlapping and distinct fibrogenic effects on human renal cells. American Journal of Physiology. Renal Physiology, Vol. 283, No. 4, (October 2002), pp. F707-F716, ISSN 0363-6127.

Grände, M., Frazen, A., Karlsson, J.O., Ericson, L.E., Heldin N.E., \& Nilsson, M. (2002). Transforming growth factor-beta and epidermal growth factor synergistically stimulate epithelial to mesenchymal transition (EMT) through a MEK-dependent mechanism in primary cultured pig thyrocytes. Journal of Cell Science, Vol. 115, No. Pt 22, (November 2002), pp. 4227-4236, ISSN 0021-9533.

Gross, M.L., Ritz, E., Schoof, A., Adamczak, M., Koch, A., Tulp, O., Parkman, A., El Shakmak, A., Szabo, A., \& Amann, K. (2004). Comparison of renal morphology in 
the Streptozotocin and the SHR/N-cp models of diabetes. Laboratory Investigation, Vol. 84, No. 4, (April 2004), pp. 452-464, ISSN 0023-6837.

Guillén, C., Martínez, P., de Gortázar, A.R., Martínez, M.E., \& Esbrit, P. (2002). Both N- and C-terminal domains of parathyroid hormone-related protein increase interleukin-6 by nuclear factor-kappa B activation in osteoblastic cells. Journal of Biological Chemistry, Vol. 277, No. 31, (August 2002), pp. 28109-28117, ISSN 0021-9258.

Harris, R.C., \& Martínez-Maldonado, M. (1995). Angiotensin II-mediated renal injury. Mineral and Electrolyte Metabolism, Vol. 21, No. 4-5, (August 1995), pp. 328-335, ISSN 0378-0392.

Henderson, J.E., Amizuka, N., Warshawsky, H., Biasotto, D., Lanske, B.M., Goltzman, D., \& Karaplis, A.C. (1995). Nucleolar localization of parathyroid hormone-related peptide enhances survival of chondrocytes under conditions that promote apoptotic cell death. Molecular and Cell Biology, Vol. 15, No. 8, (August 1995), pp. 4064-4075, ISSN 0270- 7306.

Hinz, B., Celetta, G., Tomasek, J.J., Gabbiani, G., \& Chaponnier, C. (2001). Alpha-smooth muscle actin expression upregulates fibroblast contractile activity. Molecular Biology of the Cell, Vol. 12, No. 9, (September 2001), pp. 2730-2741, ISSN 1059-1524.

Hirschberg, R. (1996). Bioactivity of glomerular ultrafiltrate during heavy proteinuria may contribute to renal tubulo-interstitial lesions: evidence for a role for insulin-like growth factor I. Journal of Clinical Investigation, Vol. 98, No. 1, (July 1996), pp. 116124, ISSN 0021-9738.

Huang, H.C., \& Preisig P.A. (2000). G1 kinases and transforming growth factor-beta signaling are associated with a growth pattern switch in diabetes-induced renal growth. Kidney International, Vol. 58, No. 1, (July 2000), pp. 162-172, ISSN 0085-2538.

Humes, H.D., Lake, E.W., \& Liu, S. (1995). Renal tubule cell repair following acute renal injury. Mineral and Electrolyte Metabolism, Vol. 21, No. 4-5, (August 1995), pp. 353365, ISSN 0378-0392.

Ishikawa, M., Akishita, M., Kozaki, K., Toba, K., Namiki, A., Yamaguchi, T., Orimo, H., \& Ouchi, Y. (2000). Expression of parathyroid hormone-related protein in human and experimental atherosclerotic lesions: functional role in arterial intimal thickening. Atherosclerosis, Vol. 152, No. 1, (September 2000), pp. 97-105, ISSN 0021-9150.

Isono, M., Mogyorósi, A., Han, D.C., Hoffman, B.B., \& Ziyadeh, F.N. (2000). Stimulation of TGF-beta type II receptor by high glucose in mouse mesangial cells and in diabetic kidney. American Journal of Physiology. Renal Physiology, Vol. 278, No. 5, (May 2000), pp. F830-F838, ISSN 0363-6127.

Izquierdo, A., López-Luna, P., Ortega, A., Romero, M., Gutiérrez-Tarrés, M.A., Arribas, I., Esbrit P., \& Bosch, R.J. (2006). The parathyroid hormone-related protein system and diabetic nephropathy outcome in streptozotocin-induced diabetes. Kidney International, Vol. 69, No. 12, (June 2006), pp. 2171-2178. ISSN 0085-2538.

Jobert, A.S., Fernandes, I., Turner, G., Coureau, C., Prie, D., Nissenson, R.A., Friedlander, G., \& Silve, C. (1996). Expression of alternatively spliced isoforms of the parathyroid hormone (PTH)/PTH-related peptide receptor messenger RNA in human kidney and bone cells. Molecular Endocrinology, Vol. 10, No. 9, (September 1996), pp. 10661076, ISSN 0888-8809. 
Kalluri, R., \& Neilson E.G. (2003). Epithelial-mesenchymal transition and its implications for fibrosis. Journal of Clinical Investigation, Vol. 112, No. 12, (December 2003), pp. 17761784. ISSN 0021-9738.

Katoh, M., Ohmachi, Y., Kurosawa, Y., Yoneda, H., Tanaka, N., \& Narita, H. (2000). Effects of imidapril and captopril on streptozotocin-induced diabetic nephropathy in mice. European Journal of Pharmacology, Vol. 398, No. 3, (June 2000), pp. 381-387, ISSN 0014- 2999.

Kaushal, G.P., Basnakian, A.G., \& Shah, S.V. (2004). Apoptotic pathways in ischemic acute renal failure. Kidney International, Vol. 66, No. 2, (August 2004), pp. 500-506, ISSN 0085-2538.

Kontogiannis, J., \& Burns, K.D. (1998). Role of AT1 angiotensin II receptors in renal ischemic injury. American Journal of Physiology. Renal Physiology, Vol. 274, No. 1-Pt2, (January 1998), pp. F79-F90, ISSN 0363-6127.

Kriz, W., Grezt, N., \& Lemley, K.V. (1998). Progression of glomerular diseases: is the podocyte the culprit?. Kidney International, Vol. 54, No. 3, (Septiembre 1998), pp. 687-697, ISSN 0085-2538.

Largo, R., Gómez-Garré, D., Santos, S., Peñaranda, C., Blanco, J., Esbrit, P., \& Egido, J. (1999). Renal expression of parathyroid hormone-related protein (PTHrP) and $\mathrm{PTH} / \mathrm{PTHrP}$ receptor in a rat model of tubulointerstitial damage. Kidney International, Vol. 55, No. 1, (January 1999), pp. 82-90, ISSN 0085-2538.

Lieberthal, W., \& Levine, J.S. (1996). Mechanisms of apoptosis and its potential role in renal tubular epithelial cell injury. American Journal of Physiology. Renal Physiology Vol. 271, No. 3 Pt2 (September 1996), pp. F477-F488, ISSN 0363-6127.

Liu, Y. (2004). Epithelial to mesenchymal transition in renal fibrogenesis: pathologic significance, molecular mechanism, and therapeutic intervention. Journal of the American Society of Nephrology, Vol. 15, No. 1, (January 2004), pp. 1-12, ISSN 10466673.

Long, G.W., Misra, D.C., Juleff, R., Blossom, G., Czako, P.F., \& Glover, J.L. (1993). Protective effects of enalaprilat against postischemic renal failure. Journal of Surgical Research, Vol. 54, No. 3, (March 1993), pp. 254-257, ISSN 0022-4804.

Lorenzo, O., Ruiz-Ortega, M., Esbrit, P., Rupérez, M., Ortega, A., Santos, S., Blanco, J., Ortega, L., \& Egido, J. (2002). Angiotensin II increases parathyroid hormone-related protein $(\mathrm{PTHrP})$ and the type $1 \mathrm{PTH} / \mathrm{PTHrP}$ receptor in the kidney. Journal of the American Society of Nephrology, Vol. 13, No. 6, (June 2002), pp. 1595-1607, ISSN 10466673.

Martínez-Estrada, O.M., Cullerés, A., Soriano, F.X., Peinado, H., Bolós, V., Martínez, F.O., Reina, M., Cano, A., Fabre, M., \& Vilaró, S. (2006). The transcription factors Slug and Snail act as repressors of Claudin-1 expression in epithelial cells. Biochemical Journal, Vol. 394, No. Pt2 (March 2006), pp. 449-457, ISSN 0264-6021.

Martín-Ventura, J.L., Ortego, M., Esbrit, P., Hernández-Presa, M.A., Ortega, L., \& Egido, J. (2003). Possible role of parathyroid hormone-related protein as a proinflammatory cytokine in atherosclerosis. Stroke, Vol. 34, No. 7, (July 2003), pp. 1783-1789, ISSN 0039-2499.

Matsumoto, K., \& Nakamura, T. (2001). Hepatocyte growth factor: renotropic role and potential therapeutics for renal diseases. Kidney Internacional, Vol. 59, No. 6, (June 2001), pp. 2023-2038, ISSN 0085-2538. 
Mezzano, S.A., Ruiz-Ortega, M., \& Egido, J. (2001). Angiotensin II and renal fibrosis. Hypertension, Vol. 38, No. 3 Pt 2, (Sep 2001), pp. 635-638, ISSN 0194911X.

Mifsud, S.A., Allen, T.J., Bertram, J.F., Hulthen, U.L., Kelly, D.J., Cooper, M.E., WilkinsonBerka, J.L., \& Gilbert, R.E. (2001). Podocyte foot process broadening in experimental diabetic nephropathy: amelioration with renin-angiotensin blockade. Diabetologia, Vol. 44, No. 4, (July 2001), pp. 878-882, ISSN 0012-186X.

Ministerio de Salud. (2005). Guía Clínica Insuficiencia Renal Crónica Terminal, (1st Ed.), Minsal, Santiago, Chile.

Muller, G.A., Markovic-Lipkovski, J., Frank, J., \& Rodemann, H.P. (1992). The role of interstitial cells in the progression of renal diseases. Journal of the American Society of Nephrology, Vol. 2, No. 10 Suppl, (April 1992), pp. S198-S205, ISSN 1046-6673.

Nakayama, T., Ohtsuru, A., Enomoto, H., Namba, H., Ozeki, S., Shibata,Y., Yokota, T., Nobuyoshi,M., Ito, M., \& Sekine, I. (1994). Coronary atherosclerotic smooth muscle cells overexpress human parathyroid hormone-related peptides. Biochemical and Biophysical Research Communications, Vo. 200, No. 2, (April 1994), pp. 1028-1035, ISSN 0006-291X.

Noda, M., Katoh, T., Takuwa, N., Kumada, M., Kurokawa, K., \& Takuwa, Y. (1994). Synergistic stimulation of parathyroid hormone-related peptide gene expression by mechanical stretch and angiotensin II in rat aortic smooth muscle cells. Journal of Biological Chemistry, Vol. 269, No. 27, (July 1994), pp. 17911-17917, ISSN 0021-9258.

Nolan, C.R., \& Anderson, R.J. (1998). Hospital-acquired acute renal failure. Journal of the American Society of Nephrology, Vol. 9, No. 4, (April 1998), pp. 710-718, ISSN 10466673.

Ortega, A., Rámila, D., Izquierdo, A., González, L., Barat, A., Gazapo, R., Bosch, R.J., \& Esbrit, P. (2005). Role of the renin-angiotensin system on the parathyroid hormonerelated protein overexpression induced by nephrotoxic acute renal failure in the rat. Journal of the American Society of Nephrology, Vol. 16, No. 4, (April 2005), pp. 939-949, ISSN 1046-6673.

Ortega, A., Rámila, D., Ardura, J.A., Esteban, V., Ruiz-Ortega, M., Barat, A., Gazapo, R., Bosch, R.J., \& Esbrit, P. (2006). Role of parathyroid hormone-related protein in tubulointerstitial apoptosis and fibrosis after folic acid-induced nephrotoxicity. Journal of the American Society of Nephrology, Vol. 17, No. 6, (June 2006), pp. 159415603, ISSN 1046-6673.

Ortiz, A., Lorz, C., Catalán, M.P., Danoff, T.M., Yamasaki, Y., Egido, J., \& Neilson, E.G. (2000). Expression of apoptosis regulatory proteins in tubular epithelium stressed in culture or following acute renal failure. Kidney International, Vol. 57, No. 3, (March 2000), pp. 969-981, ISSN 0085-2538.

Osterby, R., Hartmann, A., Nyengaard, J.R., \& Bangstad, H.J. (2002). Development of renal structural lesions in type-1 diabetic patients with microalbuminuria. Observations by light microscopy in 8-year follow-up biopsies. Virchows Archiv, Vol. 440, No. 1, (January 2002), pp. 94-101, ISSN 0945-6317.

Osterby, R., Tapia, J., Nyberg, G., Tencer, J., Willner, J., Rippe, B., \& Torffvit, O. (2001). Renal structures in type 2 diabetic patients with elevated albumin excretion rate. Acta Pathologica Microbiologica et Immunologica Scandinavica, Vol. 109, No. 11, (November 2001), pp. 751-761, ISSN 1600-0463. 
Pagtalunan, M.E., Miller, P.L., Jumping-Eagle, S., Nelson, R.G., Myers, B.D., Renke, H.G., Coplon, N.S., Sun, L., \& Meyer, T.W. (1997). Podocyte loss and progressive glomerular injury in type II diabetes. Journal of Clinical Investigation, Vol. 99, No. 2, (January 1997), pp. 342-348, ISSN 00219738.

Pantsulaia, T. (2006). Role of TGF-beta in pathogenesis of diabetic nephropathy. Georgian Medical News, Vol. 131, No. N2, (February 2006), pp. 13-18, ISSN 0016-5751.

Pirola, C.J., Wang, H.M., Kamyar, A., Wu, S., Enomoto, H., Sharifi, B., Forrester, J.S., Clemens, T.L., \& Fagin, J.A. (1993). Angiotensin II regulates parathyroid hormonerelated protein expression in cultured rat aortic smooth muscle cells through transcriptional and post-transcriptional mechanisms. Journal of Biological Chemistry, Vol. 268, No. 3, (January 1993), pp. 1987-1994, ISSN 0021-9258.

Rámila, D., Ardura, J.A., Esteban, V., Ortega, A., Ortega-Ruiz, M., Bosch, R.J, \& Esbrit, P. (2008). Parathyroid hormone-related protein promotes inflammation in the kidney with an obstructed ureter. Kidney International, Vol. 73, No. 7, (April 2008), pp. 835847. ISSN 0085-2538.

Rees, A.J. (2006). The role of infiltrating leukocytes in progressive renal disease: implications for therapy. Nature Clinical Practice. Nephrology, Vol. 2, 7, (July 2006), pp. 348-349, ISSN 1745-8331.

Remuzzi, G., \& Bertani, T. (1998). Pathophysiology of progressive nephropathies. The New England Journal of Medicine, Vol. 339, No. 20, (November 1998), pp. 1448-1456, ISSN 0028-4793.

Romero, M., Ortega, A., Izquierdo, A., López-Luna, P., \& Bosch, R.J. (2010). Parathyroid hormone-related protein induces hypertrophy in podocytes via TGF-beta(1) and p27(Kip1): implications for diabetic nephropathy. Nephrology, Dialysis, Transplantation, Vol. 25, No. 8, (August 2010), pp. 2447-2457, ISSN 0931- 0509.

Ruiz-Ortega, M., \& Egido, J. (1997). Angiotensin II modulates cell growth-related events and synthesis of matrix proteins in renal interstitial fibroblasts. Kidney International, Vol. 52, No. 6, (December 1997), pp. 1497-1510, ISSN 0085-2538.

Santos, S., Bosch, R.J., Ortega, A., Largo, R., Fernández-Agulló, T., Gazapo, R., Egido, J., \& Esbrit, P. (2001). Kidney International, Vol. 60, No. 3, (September 2001), pp. 982-995, ISSN 0085-2538.

Soifer, N.E., Van Why, S.K., Ganz, M.B., Kashgarian, M., Siegel, N.J., \& Stewart, A.F. (1993). Expression of parathyroid hormone-related protein in the rat glomerulus and tubule during recovery from renal ischemia. Journal of Clinical Investigation, Vol. 2, No. 6, (December 1993), pp. 2850-2857, ISSN 00219738.

Strutz, F., \& Müller, G.A. (2006). Renal fibrosis and the origin of the renal fibroblast. Nephrology, Dialysis, Transplantation, Vol. 21, No. 12, (December 2006), pp. 368-3370, ISSN 0931- 0509.

Strutz, F., \& Neilson, E.G. (2003). New insights into mechanisms of fibrosis in immune renal injury. Springer Seminars in Immunopathology, Vol. 24, No. 4, (May 2003), pp. 459476, ISSN 0172-6641.

Strutz, F., Zeisberg, M., Ziyadeh, F.N., Yang, C.Q., Kalluri, R., Muller, G.A., \& Neilson, E.G. (2002). Role of basic fibroblast growth factor-2 in epithelial-mesenchymal transformation. Kidney International, Vol. 61, No. 5, (May 2002), pp. 1714-1728, ISSN 0085-2538. 
Tisher, C.C., \& Hostetter, T.H. (1994). Diabetic nephropathy, In: Renal Pathology, C.C. Tisher, B.M. Brenner (Eds.), pp. 1387-1412, J.B. Lippincott Company, ISBN 0-397-51240-6, Philadelphia, USA.

U. S. Renal Data System, USRDS (2010), Annual Data Report Atlas of Chronic Kidney Disease and End Stage Renal Disease in the United States. National Institutes of Health, National Institute of Diabetes and Digestive and Kidney Diseases, Bethesda, MD, USA.

Vukicevic, S., Basic, V., Rogic, D., Basic, N., Shih, M.S., Shepard, A., Jin, D., Dattatreyamurty, B., Jones, W., Dorai, H., Ryan, S., Griffiths, D., Maliakal, J., Jelic, M., Pastorcic, M., Stavljenic, A., \& Sampath,T.K. (1998). Osteogenic protein-1 (bone morphogenetic protein-7) reduces severity of injury after ischemic acute renal failure in rat. Journal of Clinical Investigation, Vol. 102, No. 1, (July 1998), pp. 202-214, ISSN 00219738.

Watson, P.H., Fraher, L.J., Hendy, G.N., Chung, U.I., Kisiel, M., Natale, B.V., \& Hodsman, A.B. (2000). Nuclear localization of the type 1 PTH/PTHrP receptor in rat tissues. Journal of Bone and Mineral Research, Vol. 15, No. 6, (June 2000), pp. 1033-1044, 0884-0431.

White, K.E., \& Bilous, R.W. (2000). Type 2 diabetic patients with nephropathy show structural-functional relationships that are similar to type 1 disease. Journal of the American Society of Nephrology, Vol. 11, No. 9, (September 2000), pp. 1667-1673, ISSN 1046-6673.

Wolf, G., Schroeder, R., Thaiss, F., Ziyadeh, F.N., Helmchen, U., \& Stahl, R.A. (1998). Glomerular expression of p27Kip1 in diabetic $\mathrm{db} / \mathrm{db}$ mouse: role of hyperglycemia. Kidney International, Vol. 53, No. 4, (April 1998), pp. 869-879, ISSN 0085-2538.

Wolf, G., Sharma, K., Chen, Y., Ericksen, M., \& Ziyadeh, F.N. (1992). High glucose-induced proliferation in mesangial cells is reversed by autocrine TGF-beta. Kidney International, Vol. 42, No. 3, (September 1992), pp. 647-656, ISSN 0085-2538.

Wolf, G., \& Ziyadeh, F.N. (1999). Molecular mechanisms of diabetic renal hypertrophy. Kidney International, Vol. 56, No. 2, (August 1999), pp. 393-405. ISSN 0085-2538.

Xu, Z.G., Yoo, T.H., Ryu, D.R., Cheon Park, H., Ha, S.K., Han, D.S., Adler, S.G., Natarajan, R., \& Kang, S.W. (2005). Angiotensin II receptor blocker inhibits p27Kip1 expression in glucose-stimulated podocytes and in diabetic glomeruli. Kidney International, Vol. 67, No. 3, (March 2005), pp. 944-952, ISSN 0085-2538.

Yotsumoto, T., Naitoh, T., Shikada, K., \& Tanaka, S. (1997). Effects of specific antagonists of angiotensin II receptors and captopril on diabetic nephropathy in mice. Japanese Journal of Pharmacology, Vol. 75, No. 1, (September 1997), pp. 59-64, ISSN 0021-5198.

Zhuang, S., Yan, Y.,Han, J., \& Schnellmann, R.G. (2005). p38 kinase-mediated transactivation of the epidermal growth factor receptor is required for dedifferentiation of renal epithelial cells after oxidant injury. Journal of Biological Chemistry, Vol. 280, No. 22, (June 2005), pp. 21036-21042, ISSN 0021-9258.

Zhuang, S., Dang, Y., \& Schnellmann, R.G. (2004). Requirement of the epidermal growth factor receptor in renal epithelial cell proliferation and migration. American Journal of Physiology. Renal Physiology, Vol. 287, No. 3, (September 2004), F365-F372, ISSN 0363-6127.

Ziyadeh, F.N., \& Sharma, K. (2003). Overview: combating diabetic nephropathy. Journal of the American Society of Nephrology, Vol. 14, No. 5, (May 2003), pp. 1355-1357, ISSN 1046-6673. 


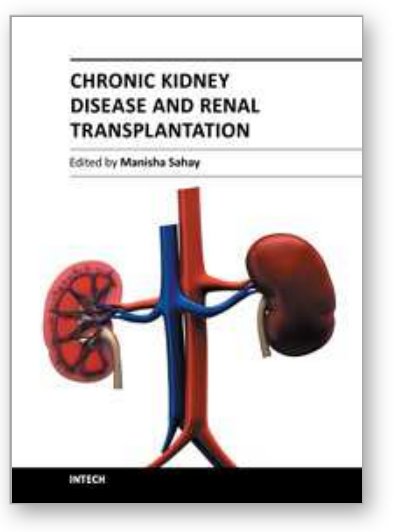

\author{
Chronic Kidney Disease and Renal Transplantation \\ Edited by Prof. Manisha Sahay
}

ISBN 978-953-51-0003-4

Hard cover, 226 pages

Publisher InTech

Published online 10, February, 2012

Published in print edition February, 2012

This valuable resource covers inpatient and outpatient approaches to chronic renal disease and renal transplant with clinical practicality. This first section of the book discusses chronic disease under distinct topics, each providing the readers with state-of-the-art information about the disease and its management. It discusses the fresh perspectives on the current state of chronic kidney disease. The text highlights not just the medical aspects but also the psychosocial issues associated with chronic kidney disease. The latest approaches are reviewed through line diagrams that clearly depict recent advances. The second section of the book deals with issues related to transplant. It provides effective and up-to-date insight into caring for your transplant patients.

\title{
How to reference
}

In order to correctly reference this scholarly work, feel free to copy and paste the following:

Ricardo J. Bosch, María Isabel Arenas, Montserrat Romero, Nuria Olea, Adriana Izquierdo, Arantxa Ortega, Esperanza Vélez, Jordi Bover, Juan C. Ardura and Pedro Esbrit (2012). Parathyroid Hormone-Related Protein as a Mediator of Renal Damage: New Evidence from Experimental as well as Human Nephropathies, Chronic Kidney Disease and Renal Transplantation, Prof. Manisha Sahay (Ed.), ISBN: 978-953-51-0003-4, InTech, Available from: http://www.intechopen.com/books/chronic-kidney-disease-and-renaltransplantation/parathyroid-hormone-related-protein-as-a-mediator-of-renal-damage-new-evidence-fromexperimental-as-

\section{INTECH}

open science | open minds

\section{InTech Europe}

University Campus STeP Ri

Slavka Krautzeka 83/A

51000 Rijeka, Croatia

Phone: +385 (51) 770447

Fax: +385 (51) 686166

www.intechopen.com

\section{InTech China}

Unit 405, Office Block, Hotel Equatorial Shanghai

No.65, Yan An Road (West), Shanghai, 200040, China

中国上海市延安西路65号上海国际贵都大饭店办公楼405单元

Phone: +86-21-62489820

Fax: $+86-21-62489821$ 
(C) 2012 The Author(s). Licensee IntechOpen. This is an open access article distributed under the terms of the Creative Commons Attribution 3.0 License, which permits unrestricted use, distribution, and reproduction in any medium, provided the original work is properly cited. 